\title{
In Memoriam - Brian C. Foster, 1952-2021
}

\author{
John Arnason ${ }^{1, *}$, Robin Marles², Cory Harris ${ }^{1,3}$, Pierre Haddad ${ }^{4}$ \\ 'Department of Biology, University of Ottawa, Ottawa, ON, Canada \\ ${ }^{2}$ Bureau of Nutritional Sciences, Food Directorate, Health Canada, Ottawa, ON, Canada \\ ${ }^{3}$ Department of Chemistry and Biomolecular Sciences, University of Ottawa, Ottawa, ON, Canada \\ ${ }^{4}$ Département de Pharmacologie et Physiologie, Université de Montréal, Montréal, QC, Canada \\ *0 Corresponding Author: john.arnason@uottawa.ca
}

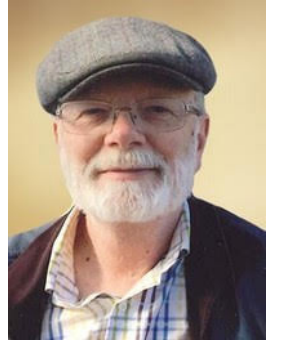

Brian Foster, $\mathrm{PhD}$, who made many contributions to Natural Health Product Research in the area of herb-drug interactions, passed away at his home in Nordegg, $\mathrm{AB}$, on Friday, October 15, 2021, at the age of 69 years. Brian is survived by his wife Deborah Lynn Foster (Cheple) and daughter Meredith.

Brian was born in Calgary, Alberta, on January 20, 1952. In 1974, he graduated from the University of Calgary with a Bachelor of Science in Microbiology. He completed his Doctorate in Pharmaceutical Science, in 1982, at the University of Alberta, under the direction of Professor Ron Coutts, with whom he studied the production of cyclosporin in culture and metabolism of amphetamines. He moved to Ottawa, Ontario, in 1984, for a post-doctoral fellowship at the Animal Research Centre, Agricultural Canada where he researched the toxicity, metabolism and elimination of mycotoxins in animals.

From 1986 to 2012, he was a Research Scientist and Senior Science Advisor for Health Canada in the Therapeutic Products Directorate (TPD). During the establishment of the Natural Health Products Directorate (NHPD) in the late 1990s, Brian was given a mandate by Health Canada to study herb-drug interactions in his capacity as an adjunct professor at the University of Ottawa's Faculty of Medicine. He published one of the first large in vitro drug interaction studies on herbal products, assessed by inhibition of cloned CYP enzymes, which has received approximately 500 citations [1]. It became the most important and widely cited scientific study of his career. This article was followed by other papers on the effects of herbal medicines on drugmetabolizing CYP isoenzymes and P-glycoproteins (e.g., [2, 3]) and over 100 other published studies on drug interactions and metabolism with his many students and collaborators.

In his role as a Senior Science Advisor at TPD, Brian generously provided scientific advice to his colleagues in the fledgling NHPD. His extensive knowledge and thorough review contributed to such matters as NHP safety assessment, phytochemical analysis for the identity and quality of NHPs, peer review of scientific rationales for Health Canada's decisions not to allow the marketing of certain potentially dangerous or fraudulent products to Canadian consumers, and even supporting testimony as an expert witness in a court case challenging one of these decisions by Health Canada.

After leaving Health Canada, Brian maintained his position at the University of Ottawa, committing his time and energy to training the next generation of toxicologists and Natural Health Product researchers. Brian played a major role in the study by the Team in Aboriginal Antidiabetic Medicines headed by Pierre Haddad, Université de Montréal. He was principal investigator in the area of safety assessments and drug interactions of foods, medicines and teas used by the James Bay Cree for treatment of Type 2 diabetes. These studies have led to the safe implementation of traditional medicinal teas and foods for Type 2 diabetes in four First Nations across Canada.

Brian had a passion for Celtic music and organized music evenings for friends and students. He also had a project to escape Ottawa by building a vacation and retirement home in the spectacular mountain country of Nordegg, AB. Brian and his wife moved to Nordegg full time in 2020 and in his last year, Brian took full advantage of hiking, snowshoeing and gardening there.

Given his professional passion for protecting the health of Canadians and his kind dedication to friends, 
his favourite parting word of "Sláinte" (Irish for "health") meant to us his wish for health not only personally but to all people. He is sorely missed already.

\section{References}

[1] Budzinski JW, Foster BC, Vandenhoek S, Arnason JT. An in vitro evaluation of human cytochrome P450 3A4 inhibition by selected commercial herbal extracts and tinctures. Phytomedicine 2000;7(4):s273-282. https://doi.org/10.1016/S0944-7113(00)80044-6
[2] Scott IM, Leduc RI, Burt AJ, Marles RJ, Arnason JT, Foster BC. The inhibition of human cytochrome P450 by ethanol extracts of North American botanicals. Pharmaceutical Biology 2006;44(5):315-327. https://doi.org/10.1080/13880200600746196

[3] Chauhan B, Yu C, Krantis A, Scott I, Arnason JT, Marles $\mathrm{RJ}$, Foster BC. In vitro activity of uva-ursi against cytochrome P450 isoenzymes and P-glycoprotein. Canadian Journal of Physiology and Pharmacology 2007;85(11): 1099-1107. https://doi.org/10.1139/Y07-106

\section{Article Information}

Managing Editor: Pierre Haddad, Kieran Cooley

Article Date: Published Jan 1222

\section{Citation}

Please cite this article as follows:

Arnason J, Marles R, Harris C, Haddad P. In Memoriam - Brian C. Foster, 1952-2021. Journal of Natural Health Product Research. 2022 Jan 12: 4(1). https://jnhpresearch.com/index.php/jnhpr/article/view/23

DOI Link: https://doi.org/10.33211/jnhpr.23

\section{Copyright}

(C) John Arnason, Robin Marles, Cory Harris, Pierre Haddad (2022). Published first in the Journal of Natural Health Product Research. This is an open access article distributed under the terms of the Creative Commons Attribution License (https://creativecommons.org/licenses/by/4.0/), which permits unrestricted use, distribution, and reproduction in any medium, provided the original work, first published in the Journal of Natural Health Product Research, an NHP Publications journal, is properly cited. The complete bibliographic information, a link to the original publication on https://www.jnhpresearch.com, as well as this copyright and license information must be included.

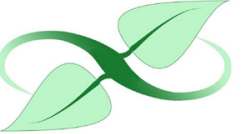

Canadà

Does the safety, efficacy, and quality of natural health products matter to YOU? Submit your research article to the Journal of Natural Health Product Research!

Pre-submission inquiries? Send us an email at editorial.office@jnhpresearch.com Find us on Facebook, Twitter and LinkedIn 